\title{
Clarifying closure scenarios through integrated planning at the Cerrejón mine in Colombia
}

\author{
J Ricaurte Cerrejón Coal Mine, Colombia \\ CD Grant Anglo American, Australia \\ A Freitas Golder Associates Brasil Consultoria e Projetos Ltda., Brazil \\ PR Botha Anglo American, South Africa
}

\begin{abstract}
Cerrejón is an export thermal coal mine in Colombia producing 30 million tonnes per annum (mtpa) and employing more than 6,000 direct employees. Operated since 1985, Cerrejón mine is a joint venture operation between Anglo American (AA), BHP and Glencore. The first Cerrejón mine closure plan (MCP) was produced in 2009, with subsequent updates in 2012 and 2016. Since 2009, the MCPs have followed the guidance of the AA Mine Closure Toolbox (MCT). In 2018, the shareholders of Cerrejón requested that the closure plan be updated for two scenarios: reversion of the lease to the State in 2033 and planned closure of the operation. Cerrejón engaged AA Group Technical and Sustainability to assist with the update of the closure plan, incorporating the Integrated Closure Planning System (ICPS) developed by AA in 2015. The ICPS process complements and enhances the MCT process, with the focus of integrating closure planning into life-of-mine (LOM) planning and, in doing so, moving from just planning to operational execution. The first step in the ICPS process involved a baseline maturity assessment during a multifunctional site-based workshop. A plan was developed to improve subprocesses of the ICPS where the current maturity condition was below the competence level. Implementation of the plan commenced in 2018. Key components of the plan include an integrated planning opportunities workshop using Kepner-Tregoe analysis to prioritise identified projects, updating the baseline closure risk assessment, redoing the gap analysis in relation to the requirements of the $M C T$, benchmarking options to mitigate closure risks, developing closure and success criteria, and updating the existing closure plan and associated liability with an action plan to address gaps. This paper provides detail on how utilising the ICPS process assisted in clearly defining the reversion and closure cases, and the major risks, opportunities and gaps at Cerrejón mine-adding value not only by improving the confidence in the updated closure plan and costing but also by defining a clear way forward in integrating closure planning into the remaining LoM planning.
\end{abstract}

Keywords: Cerrejón mine, integrated closure planning, cases analysis, opportunities assessment

\section{Introduction}

Cerrejón is one of the largest open pit coal-export mining operations in the world. The company is an important player in the Colombian economy and the driving power of La Guajira State, the arid region where the production activity takes place, generating about $47 \%$ of its gross domestic product (Cerrejón 2018). Activities include exploration, extraction, transportation, loading on ships and export of coal of various qualities largely to markets in Europe. Cerrejón operations began in 1985 under an association contract between Exxon Mobil Corporation and Carbocol, with mining contracts projected up to 2009. In 2002, the site was acquired by Anglo American (AA), BHP and Glencore, and some years after the mining contracts were extended until 2034. The operations currently take place in seven different open pits within a lease area of about $35,000 \mathrm{~km}^{2}$ split into five different contracts. Cerrejón structures also include a port and a $150 \mathrm{~km}$ long railway connecting the mine to the port. 
Grant \& Botha (2015) provided three case studies from AA operations around the globe where integrated closure planning opportunities had been realised, generating value in excess of USD 200 million through eliminating risks or prevention of value destruction. Based on the success of these case studies, AA commenced the development of an Integrated Closure Planning System (ICPS) in 2014. The preliminary development of the ICPS involved the identification of current and target conditions, and an initial maturity assessment across more than 50 operations, as described in Grant \& Lacy (2016). AA's ICPS objective is to combine the various mine planning regimes; internal and external requirements; and financial considerations and systems from a people, process and technology perspective, over the lifecycle of operations, to ensure AA optimises use of its resources and leaves a positive and sustainable legacy for their host communities post-closure. Grant et al. (2016) reported on the completion of the first ICPS pilot assessment at the Kolomela mine in the Northern Cape of South Africa at the first Planning for Closure workshop in Santiago.

Although Cerrejón has been undertaking concurrent rehabilitation activities for more than 30 years, its first mine closure plan (MCP) was fully documented in 2009 and aligned with the AA Mine Closure Toolbox (MCT) methodology (risk-based approach to closure planning). To create this plan, a detailed legal analysis was carried out in order to identify closure requirements. Briefly, this analysis, which is still valid, concluded that Cerrejón's closure requirements come from the mining contracts and the environmental management plan (EMP). Specifically, the mining contracts demand that Cerrejón must 'leave active the mines that are still productive; revert assets and other properties located in the lease area to the mining authority; restore area conditions according to environmental provisions; and return the railroad and the port infrastructure to the government when the last mining contract expires.' The legal review also demonstrated the absence of closure regulations and therefore suggested to analyse different cases. Thus, three cases were created at that time:

1. Reversion, an operational mine and all assets will revert to the government at the end of mining contracts.

2. Partial Closure, the mine will close partially and some assets will be dismantled.

3. Full Closure, the mine will close entirely and all infrastructure will be dismantled.

In 2012, during the first MCP update, only two cases were considered: Reversion and Partial Closure. In 2016, the MCP was updated again, but due to the existing global financial crisis, it was decided to consider the Reversion case only. This update recommended to consider alternate cases in order to be prepared for future closure legislation or market changes. Therefore, it was decided in 2018 to again update the MCP using the AA ICPS methodology, to evaluate the corporate risk exposure due to the legal uncertainties and the absence of closure regulations. As a result, two cases were considered during the 2018-2019 MCP update: Reversion and Full Closure. The major objective of this paper is to provide detail on how utilising the ICPS process assisted in clearly defining the reversion and closure cases and the major risks, opportunities and gaps at Cerrejón mine in Colombia.

\section{Maturity assessment and development of the closure plan update}

A baseline assessment was undertaken comparing the current maturity at Cerrejón to the targeted level for the ICPS of four (on a scale of 1-5). The maturity assessment process has previously been described in Grant et al. (2016). Of the 33 relevant subprocesses to Cerrejón, 11 were already at the desired maturity level of four or above (Figure 1). For the remaining 22 subprocesses, a detailed action plan-along with a schedule-was developed to address the gaps. Tasks were split between Cerrejón staff, AA Group Technical and Sustainability, and Golder Associates. 
1.1 Establish Physical and Bio-Physical Context 1.2 Establish Social And Economic Context 1.3 Determine Int/Ext Requirements 1.4 Closure Risk Assessment

2.1 Evaluate Stakeholder Expectations 2.2 Evaluate LoM plan, design and schedules 2.3 Evaluate Conditions and Commitments 2.4 Benchmark Closure Options

2.5 Define Closure Vision

3.1 Closure Options and Cost Benefit Analysis 3.2 Identify Mine Planning Opportunities 3.3 Define Detailed Objectives and Criteri

3.4 Develop Progressive Rehabilitatio Strategy 3.5 Establish Success Criteria

3.6 Develop Draft Monitoring Program

3.7 Undertake Gap Analysis

3.8 Estimate LoM Closure liability

3.9 Develop Preliminary Closure Plan

4.1 Identify Required Actions

4.2 Identify Who, When and Cost

4.3 Obtain Sign-off of Defined Action Plans

4.4 Develop Closure Planning KPIs

5.1 Execution of Action Plans

5.2 Implement Progressive Rehabilitation Plan

5.3 Implement Stakeholder Engagement Plan

5.4 Validate Critical Control Effectiveness

5.5 Update closure plan and liability

6.1 Finalise the Monitoring Program

6.2 Compare Results To Success Criteria

6.3 Develop Maintenance Action Plan

6.4 Implement a Post Closure Management Plan

6.5 Update the Closure Plan and Liability

6.6 Internal and External Reporting

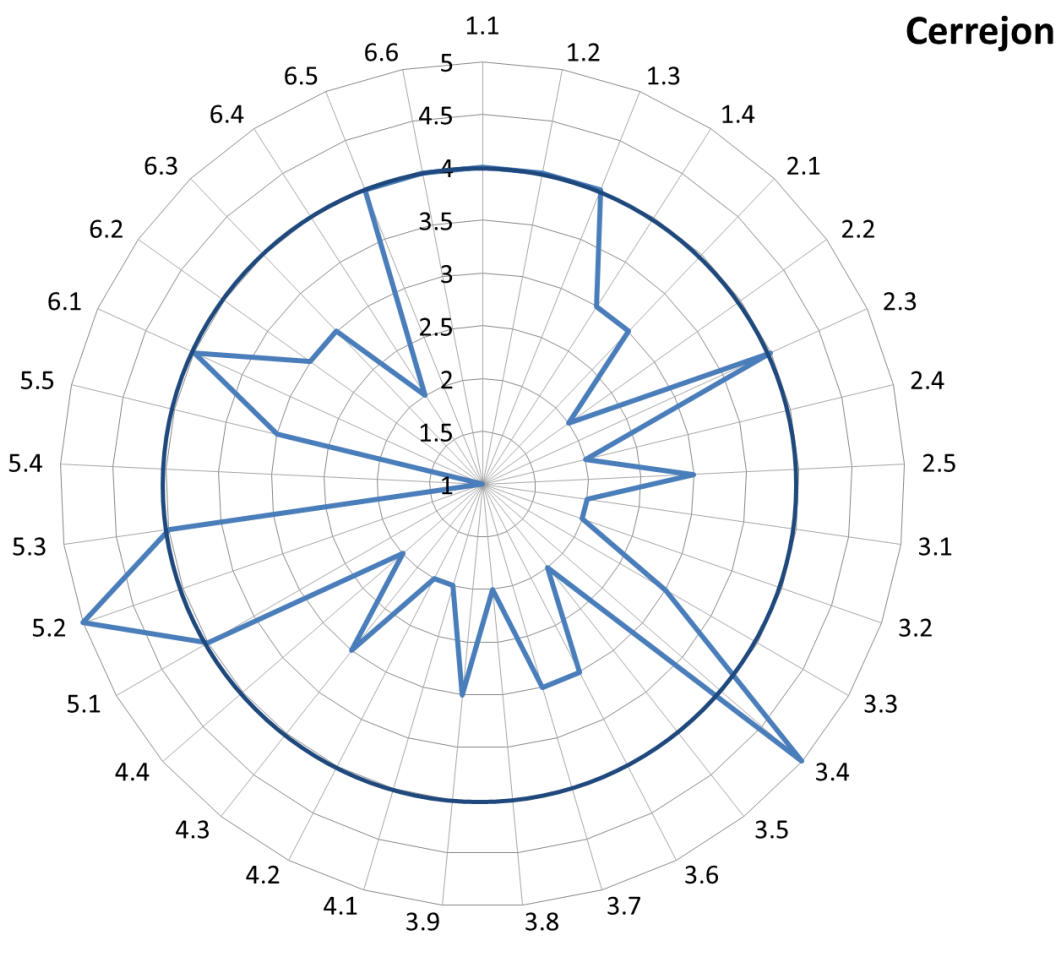

Figure 1 Baseline maturity assessment for Cerrejón mine. The darker blue line represents the target maturity state for the pilot site

\section{Implementation of the plan}

Six major areas were identified in the implementation plan to facilitate the update of the closure plan and associated liability, namely to conduct an integrated planning opportunities workshop, update the baseline closure risk assessment, redo the gap analysis, develop and implement closure-related key performance indicators (KPIs) for senior leaders, benchmark options to mitigate closure risks, and develop closure and success criteria. These components are described in more detail below.

\subsection{Opportunities analysis}

One of the most critical components of the ICPS is to improve integration of mine and closure planning (short, medium and LoM). To facilitate this, a workshop was conducted involving a variety of functions across Cerrejón to identify and prioritise integrated planning opportunities. A Kepner-Tregoe (KT) decision analysis tool was used, and the methodology with examples is described in Grant et al. (2018). The first component of the workshop involved brainstorming opportunities, the second was populating the KT methodology to prioritise the options, and third was engaging in the development of plans to further investigate the opportunity. The brainstormed opportunities were then narrowed down to six (Figure 2), and detailed implementation plans were developed for the top four opportunities: optimising water management, alternative livelihoods for communities, improved management of spontaneous combustion, and early backfill options. Significant value was realised through detailed examination of the prioritised opportunities. 

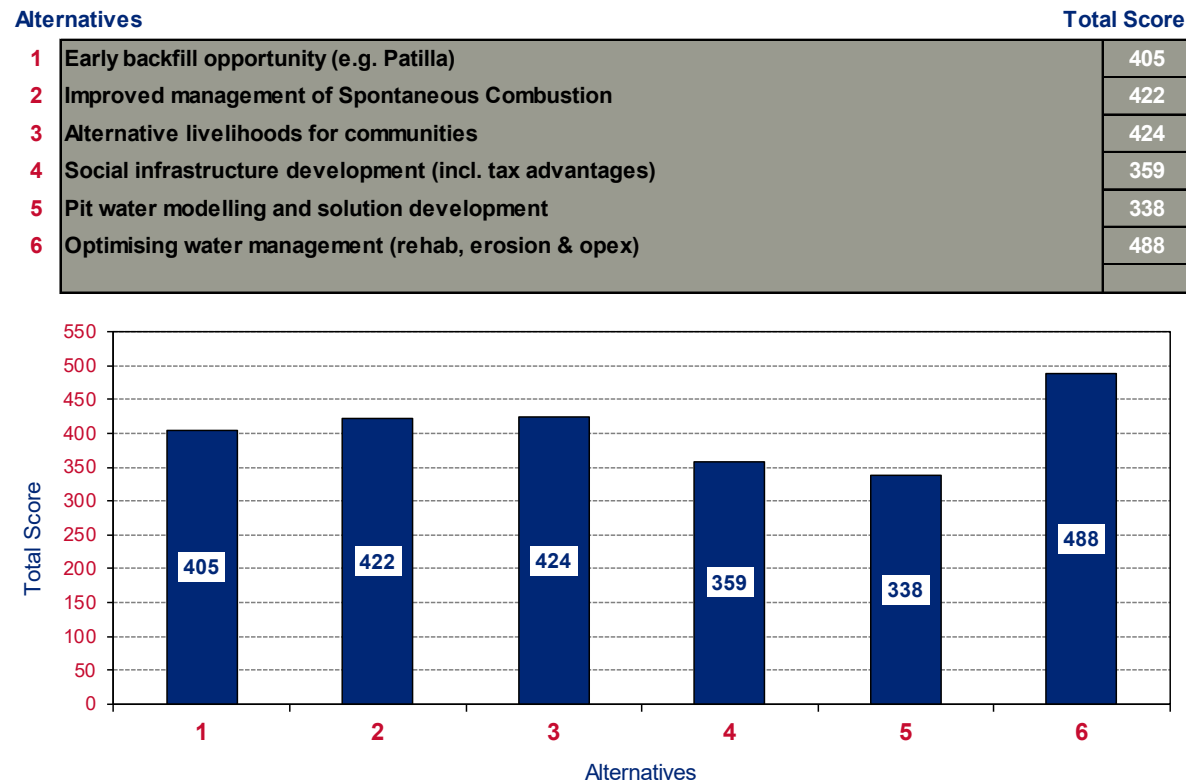

Figure 2 Final scoring for the top six opportunities at Cerrejón mine

\subsection{Risk assessment}

Following a risk-based approach to closure planning and execution is fundamental to the MCT and ICPS processes. A formal risk assessment using the Australian/New Zealand Risk Management Principles and Guidelines (Council of Standards Australia \& Council of Standards New Zealand 2009) was conducted in order to understand the risks for mine closure that need to be mitigated by the closure planning process. This process is vital to define the closure criteria (also named closure measures) as presented in Figure 3 , where the risk of potential events and impacts occurring are assessed through a series of risk categories, before and after the application of control measures. The outcome of this analysis is the identification of potential closure criteria.
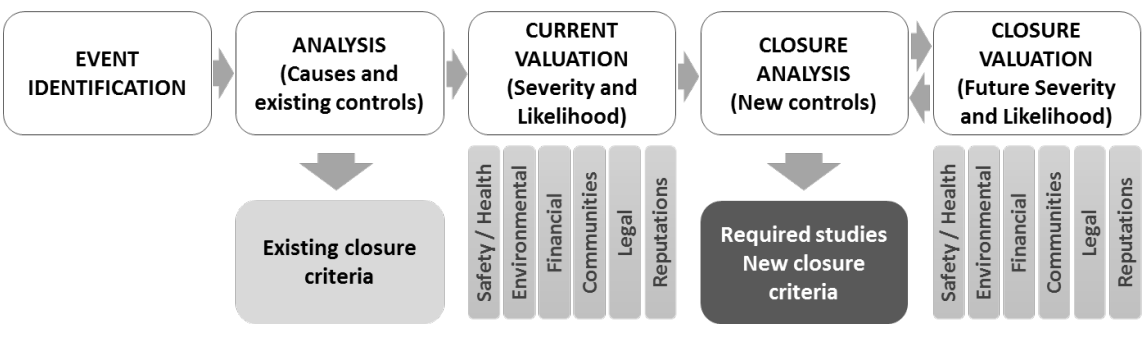

Figure 3 Risk assessment approach. This figure explains the steps applied to conduct the risk analysis, highlighting where closure criteria can be identified

The risk assessment approach was applied for the two cases under consideration throughout several multidisciplinary workshops. The analysis began with the identification of all the risk events with their causes and existing controls for the Full Closure case and then the Reversion case. Next, the risk events were grouped into three broad categories, namely physical, biophysical and social, and then grouped by element within each category (e.g. mining areas, biodiversity, affected parties and others). Subsequently, with the causes and existing controls in place, an initial valuation was made for every risk event to evaluate the impact in relation to the probability that the event will occur.

The valuation is based on a six by seven categories/levels severity matrix, which is used to assess the consequence of an identified event, and a six levels likelihood matrix, which is used to assess the probability that the worst consequence will materialise. Thus, the risk event value was calculated as the multiplication of the factors identified through the severity and likelihood matrixes. 
After having the initial valuation and as part of the workshops, new potential closure criteria to reduce the severity or likelihood of the events were identified. Then, assuming that the new measures would be in place during the closure and post-closure periods, all the risk events were evaluated again, defining a residual risk rating (RRR) for each event (Figure 4). The measures were classified as studies or controls. The first group consisted of measures to reduce uncertainties about the risks or to evaluate effectiveness of the existing controls (e.g. studies to verify potential for acid rock drainage and metal leaching). The second group consisted of controls to reduce these risks. Finally, these controls were incorporated to the updated set of closure criteria, which were used in the MCP update process.

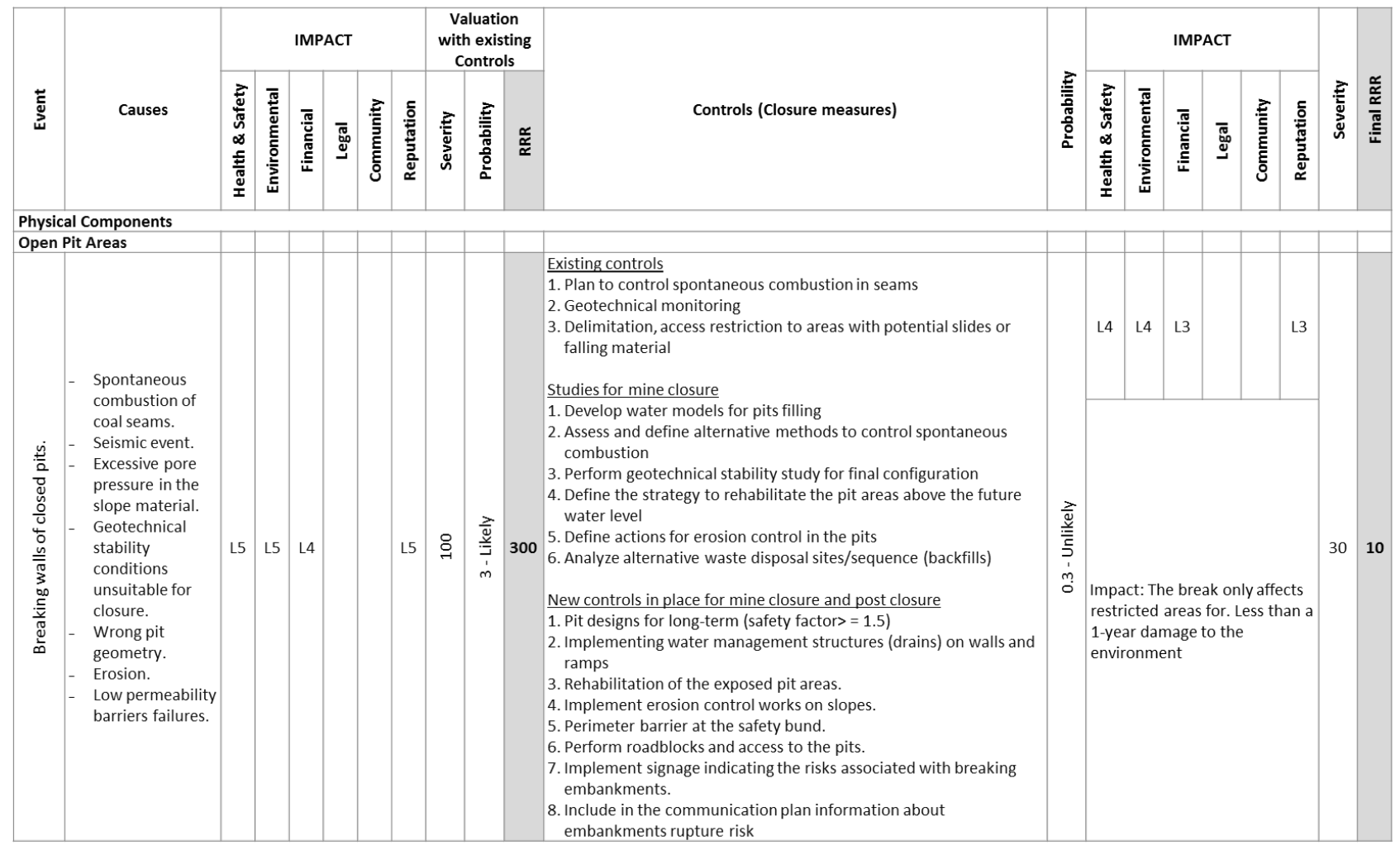

Figure 4 Risk assessment matrix. This figure shows the template used to capture the different pieces of information for the steps required to conduct the risk assessment. Also, one risk event as an example to illustrate the process is shown

The closure risk assessment identified 15 risk events for each case (Reversion and Full Closure) split into the three broad categories of physical, biophysical and social. The risks were similar for both cases with differences principally on the RRRs or the control measures. For the Full Closure case, 10 risk events were initially valuated as material events (i.e. risks with a RRR equal or higher than 90). As per the described methodology, the second valuation was made after the identification of new studies or controls and assuming these will be in place before the beginning of the closure period. This second valuation, ended in just three events classified as material, demonstrating the relevance of the new controls. The numbers were the same for the Reversion case. This similarity can be explained due to the existing socio-economic conditions in the region, the existing technical challenges, the uncertainties in the mine closure process, and the corporate mandate to undertake closure in a responsible manner.

These three material residual risks were:

1. Spontaneous combustion of coal seams after closure.

2. Pollution of superficial or groundwater after closure.

3. Deterioration of the socio-economic conditions in the region. 
These risks have potential impacts on three of the six severity categories including Environment, Communities and Reputation-and the probabilities were classified as either possible or higher.

\subsection{Gap analysis}

The cornerstone of the AA MCT involves undertaking a gap analysis across the physical, biophysical and socio-economic aspects of closure based on defined levels of detail that relate to the remaining LoM (Botha 2013). The concept of the gap analysis involves having the required level of detail in closure criteria and associated costing based on the remaining LoM.

A preliminary gap analysis was undertaken for Cerrejón in 2007 and then subsequently updated in 2009, 2016 and 2019. The 2019 analysis included the assessment of 65 aspects of closure. Fourteen of these items were evaluated as meeting the level of information required for a draft closure plan, corresponding to a remaining LoM of between 10 and 15 years, that was applicable for Cerrejón in 2019. The remaining 51 items were evaluated as having insufficient level of information to meet the requirements for a draft closure plan. Aiming to fill this gap of information, a total of $\mathbf{8 6}$ actions were proposed to be completed over a period of approximately three years.

Table 1 presents an extract of the gap analysis performed for Cerrejón mine in 2019. This table displays the structure of the gap analysis (Tool 2 of the AA MCT) where each item was put in the matrix and its associated closure criteria were compared against the AA MCT depending the remaining LoM. If closure criteria were located at any column at the left side of the 15-10 year column, it indicated a gap and therefore actions to close the gaps were proposed in the right side column (Tool 3 of the AA MCT).

Table 1 Cerrejón gap analysis. This table is an extract that includes two items as examples (cont. next page)

\begin{tabular}{|c|c|c|c|c|}
\hline \multicolumn{4}{|c|}{ Tool 2: Rapid assessment of the status-closure scenario } & Tool 3: Closing the gaps \\
\hline $\begin{array}{l}\text { Remaining } \\
\text { time to } \\
\text { scheduled } \\
\text { closure }\end{array}$ & $\begin{array}{l}\text { More than } 25 \\
\text { years }\end{array}$ & $25-15$ years & $15-10$ years & \multirow[t]{2}{*}{ Actions to close the gaps } \\
\hline $\begin{array}{l}\text { Item } \\
\text { description }\end{array}$ & \multicolumn{2}{|c|}{ Preliminary closure plan } & $\begin{array}{l}\text { Draft closure } \\
\text { plan }\end{array}$ & \\
\hline \multicolumn{5}{|c|}{ Physical closure of infrastructure/mining areas } \\
\hline \multicolumn{5}{|c|}{ Mining surface structures } \\
\hline $\begin{array}{l}\text { Industrial area } \\
\text { and processing } \\
\text { plant }\end{array}$ & $\begin{array}{l}\text { Assumed closure } \\
\text { criteria }\end{array}$ & $\begin{array}{l}\text { Revised closure } \\
\text { criteria }\end{array}$ & $\begin{array}{l}\text { Proven closure } \\
\text { criteria (No } \\
\text { Gap) }\end{array}$ & \multirow{2}{*}{$\begin{array}{l}\text { Develop an inventory of } \\
\text { structures considering current } \\
\text { conditions and projection at } \\
\text { the date of closure. } \\
\text { Develop an initial demolition } \\
\text { and dismantling plan. The plan } \\
\text { must include assumptions } \\
\text { regarding the use of equipment } \\
\text { and labour, and location of } \\
\text { final disposition sites for each } \\
\text { type of material. } \\
\text { Develop an estimation of } \\
\text { demolition and dismantling } \\
\text { costs. }\end{array}$} \\
\hline $\begin{array}{l}\text { Reference: } \\
\text { Mining } \\
\text { contracts } \\
\text { Mine closure } \\
\text { plan } \\
\text { Environmental } \\
\text { management } \\
\text { plan } \\
\text { Gap analysis } \\
\text { workshop }\end{array}$ & $\begin{array}{l}\text { Initial cost } \\
\text { estimate (Gap) }\end{array}$ & Class 0 estimate & $\begin{array}{l}\text { Improved class } \\
0 \text { estimate }\end{array}$ & \\
\hline
\end{tabular}




\begin{tabular}{|c|c|c|c|c|}
\hline \multicolumn{5}{|c|}{ Waste rock dumps (WRDs) } \\
\hline $\begin{array}{l}\text { WRDs type I- } \\
\text { Potentially acid } \\
\text { generating } \\
\text { (ARD) } \\
\text { materials } \\
\text { WRDs type II - } \\
\text { Uncertainty } \\
\text { regarding acid } \\
\text { rock drainage }\end{array}$ & $\begin{array}{l}\text { Assumed closure } \\
\text { criteria (Gap) }\end{array}$ & $\begin{array}{l}\text { Revised closure } \\
\text { criteria }\end{array}$ & $\begin{array}{l}\text { Proven closure } \\
\text { criteria }\end{array}$ & $\begin{array}{l}\text { Perform complete geochemical } \\
\text { study, including static and } \\
\text { kinetic tests for the evaluation } \\
\text { of the potential for the } \\
\text { generation of ARD/leaching in } \\
\text { the dumps. } \\
\text { For dumps that confirm } \\
\text { potential generation of ARD or } \\
\text { significant leaching of metals: }\end{array}$ \\
\hline $\begin{array}{l}\text { Reference: } \\
\text { Mining } \\
\text { contracts } \\
\text { Mine closure } \\
\text { plan } \\
\text { Environmental } \\
\text { management } \\
\text { plan } \\
\text { Gap analysis } \\
\text { workshop }\end{array}$ & $\begin{array}{l}\text { Initial cost } \\
\text { estimate (Gap) }\end{array}$ & Class 0 estimate & $\begin{array}{l}\text { Improved class } \\
0 \text { estimate }\end{array}$ & $\begin{array}{l}\text { Estimation of percolation flows } \\
\text { from dumps to groundwater } \\
\text { and surface water. } \\
\text { Long-term estimation of } \\
\text { groundwater and surface water } \\
\text { quality that might be impacted } \\
\text { by percolation from dumps. } \\
\text { Perform water quality } \\
\text { monitoring (seepage) of dumps } \\
\text { already rehabilitated. } \\
\text { For all dumps: } \\
\text { Perform geotechnical stability } \\
\text { study for the final pit } \\
\text { configuration (static and } \\
\text { pseudo-static conditions). } \\
\text { Perform seismic hazard study } \\
\text { for the use of data in the } \\
\text { geotechnical stability study. }\end{array}$ \\
\hline
\end{tabular}

\subsection{KPIs for senior leaders}

A challenge for integrated closure planning has been a lack of responsibility for closure-related issues and their attribution to key functions onsite (e.g. planning, production, finance). This is addressed through the ICPS, with a key subprocess, by identifying KPIs for senior leaders at the company, business unit and site levels. A standard suite of KPIs has been developed by the AA closure team, and these KPIs were adapted for Cerrejón, signed off by the leadership team and included in 2019 performance contracts. These KPIs focus on meeting progressive rehabilitation targets, identifying opportunities for integrated planning, decreasing closure liability and completing the necessary actions to update the existing closure plan and meet the requirements of the ICPS. In addition, based on the ICPS implementation outcomes, a set of KPIs will also be defined for following years leading up to the next MCP update, which is expected to take place in 2022. These indicators will seek execution of studies and actions to close the identified gaps as part of the implementation of the ICPS and update of the MCP.

\subsection{Benchmarking exercise}

The Cerrejón benchmarking was undertaken as a desktop exercise focusing on key risks previously identified as significant or high post-implementation of existing closure criteria within the existing closure risk assessment. The areas for further investigation were:

- Control of spontaneous combustion in the open pits.

- Long-term geotechnical stability of pit walls and WRDs. 
- Surface water management and erosion control.

- Rehabilitation/revegetation approaches and techniques.

- Long-term access control to areas with relevant safety risks post-closure (e.g. open pits with high walls).

Following a high-level search of existing studies from similar mining scenarios at an international, national, regional and local scale, closure criteria were identified for more detailed examination. The ICPS process seeks to drive an analytical comparison of the existing closure criteria, with high residual risk, with similar closure criteria discovered through the benchmarking process. Ultimately, benchmarking seeks to reduce the current closure and long-term post-closure residual risk profile, improve the closure criteria and reduce the closure liability by identifying best practice that can be implemented to achieve the same or better residual risk profile but at a lesser cost.

\subsection{Closure and success criteria}

Closure criteria are the agreed tasks involved in mitigating identified closure risks (e.g. removal of infrastructure, reshaping, seeding and planting, maintenance and monitoring). As supported by the International Council on Mining and Metals (ICMM 2019), success criteria are the agreed standards that must be met to facilitate lease relinquishment and include physical, biophysical and socio-economic parameters and are generally defined through engagement with regulators and other external stakeholders (e.g. species richness and density measures, water quality parameters, erosion measures, redeployment percentages, health facility availability). The adequacy of existing closure criteria was assessed as part of the ICPS risk assessment review. Additional closure criteria were added for areas where the residual risk remained significant or high, some of which were assessed in the benchmarking exercise. As success criteria had not been previously identified in the Cerrejón closure plan, it was decided that the structure utilised by Alcoa in Western Australia that had successfully led to the relinquishment of parts of the Jarrahdale mine (Grant 2006) would be utilised due to demonstrated success. Principles and time categories were developed-along with criteria and intent, relevant domains, guidelines for acceptance, accepted standard and potential corrective actions-for each success criteria (Table 2). These were then aligned with the existing monitoring program to ensure alignment so that areas could be assessed and requirements for maintenance (corrective action) identified if appropriate.

Table 2 Extract from the Cerrejón success criteria. Template used to develop success criteria proposal which was filled out from left to right during a series of multidisciplinary workshops (cont. next page)

\begin{tabular}{|c|c|c|c|c|c|c|}
\hline \multirow{2}{*}{ Principles } & \multirow{2}{*}{$\begin{array}{l}\text { Criteria/ } \\
\text { intent }\end{array}$} & \multirow{2}{*}{ Domain } & \multicolumn{2}{|l|}{ Success criteria } & \multirow{2}{*}{ Case } & \multirow{2}{*}{$\begin{array}{l}\text { Potential } \\
\text { corrective actions }\end{array}$} \\
\hline & & & Indicator & Target & & \\
\hline \multirow{2}{*}{$\begin{array}{l}\text { Public health } \\
\text { and safety: } \\
\text { Ensure the } \\
\text { area is } \\
\text { maintained in } \\
\text { safe } \\
\text { conditions in } \\
\text { long-term } \\
\text { and without } \\
\text { potential } \\
\text { human } \\
\text { health } \\
\text { impacts }\end{array}$} & $\begin{array}{l}\text { No } \\
\text { invasions } \\
\text { after closure }\end{array}$ & $\begin{array}{l}\text { Closure of } \\
\text { infrastructure } \\
\text { (all areas) }\end{array}$ & $\begin{array}{l}\text { Number of } \\
\text { invasions after } \\
\text { closure }\end{array}$ & Zero per year & Closure & $\begin{array}{l}\text { Improve access } \\
\text { control }\end{array}$ \\
\hline & $\begin{array}{l}\text { Human } \\
\text { health risk } \\
\text { in } \\
\text { acceptable } \\
\text { levels }\end{array}$ & $\begin{array}{l}\text { Closure of } \\
\text { infrastructure } \\
\text { (all areas) }\end{array}$ & $\begin{array}{l}\text { Human health } \\
\text { risk associated } \\
\text { with } \\
\text { contamination } \\
\text { of soil, surface } \\
\text { and } \\
\text { groundwater }\end{array}$ & $\begin{array}{l}\text { Does not } \\
\text { exceed } \\
\text { acceptable } \\
\text { national and } \\
\text { international } \\
\text { standards }\end{array}$ & $\begin{array}{l}\text { Closure, } \\
\text { Reversion }\end{array}$ & $\begin{array}{l}\text { Implement } \\
\text { remediation } \\
\text { measures to reduce } \\
\text { contamination } \\
\text { and/or contaminant } \\
\text { transport and/or } \\
\text { increase land use } \\
\text { restriction in } \\
\text { contaminated areas } \\
\text { to reduce receptor } \\
\text { exposure }\end{array}$ \\
\hline
\end{tabular}




\begin{tabular}{|c|c|c|c|c|c|c|}
\hline \multirow{2}{*}{ Principles } & \multirow{2}{*}{$\begin{array}{l}\text { Criteria/ } \\
\text { intent }\end{array}$} & \multirow{2}{*}{ Domain } & \multicolumn{2}{|l|}{ Success criteria } & \multirow{2}{*}{ Case } & \multirow{2}{*}{$\begin{array}{l}\text { Potential } \\
\text { corrective actions }\end{array}$} \\
\hline & & & Indicator & Target & & \\
\hline \multirow{3}{*}{$\begin{array}{l}\text { Physical } \\
\text { stability: } \\
\text { Ensure the } \\
\text { area is } \\
\text { maintained in } \\
\text { stable } \\
\text { conditions in } \\
\text { long-term, } \\
\text { with low } \\
\text { potential for } \\
\text { displacement } \\
\text { of soil and } \\
\text { rocks }\end{array}$} & \multirow{2}{*}{$\begin{array}{l}\text { Adequate } \\
\text { geotechni- } \\
\text { cal stability } \\
\text { in long- } \\
\text { term }\end{array}$} & $\begin{array}{l}\text { Closure of } \\
\text { infrastructure } \\
\text { (WRDs) }\end{array}$ & $\begin{array}{l}\text { Slope } \\
\text { deformation } \\
\text { rate }\end{array}$ & $\begin{array}{l}\text { To be defined } \\
\text { based on } \\
\text { geotechnical } \\
\text { monitoring } \\
\text { data and } \\
\text { analysis }\end{array}$ & Closure & $\begin{array}{l}\text { Implement } \\
\text { additional actions } \\
\text { aiming to increase } \\
\text { geotechnical } \\
\text { stability }\end{array}$ \\
\hline & & $\begin{array}{l}\text { Closure of } \\
\text { infrastructure } \\
\text { (open pits) }\end{array}$ & $\begin{array}{l}\text { Number of } \\
\text { cracks in the } \\
\text { safe perimeter } \\
\text { along the crest } \\
\text { of the open pit }\end{array}$ & Zero & Closure & $\begin{array}{l}\text { Implement } \\
\text { additional actions } \\
\text { aiming to increase } \\
\text { geotechnical } \\
\text { stability }\end{array}$ \\
\hline & $\begin{array}{l}\text { Adequate } \\
\text { erosion } \\
\text { control in } \\
\text { long-term }\end{array}$ & $\begin{array}{l}\text { Closure of } \\
\text { infrastructure } \\
\text { (WRDs) }\end{array}$ & $\begin{array}{l}\text { Number of } \\
\text { significant } \\
\text { erosion points } \\
\text { (i.e. more than } \\
1 \mathrm{~m} \text { depth and } \\
15 \mathrm{~m} \text { long) } \\
\text { identified in the } \\
\text { post-closure } \\
\text { monitoring }\end{array}$ & Zero per year & $\begin{array}{l}\text { Closure, } \\
\text { Reversion }\end{array}$ & $\begin{array}{l}\text { Fix erosion points. } \\
\text { Evaluate and } \\
\text { adjust, if necessary } \\
\text { drainage and } \\
\text { vegetation cover }\end{array}$ \\
\hline
\end{tabular}

\section{$4 \quad$ Update closure plan}

In 2019, a draft closure plan was prepared for Cerrejón mine, consolidating the information produced in the steps described earlier in this paper. Closure and success criteria were defined for both, the Reversion and the Closure cases, following the preparation of closure cost estimates for each case. For the Reversion case, actual closure criteria were considered only for structures that would be exhausted (e.g. Patilla open pit) or not operative by the date planned for reversion (2033), while the remaining structures were considered to be maintained in proper operating conditions until this date, as required in the mining contract. The closure scenario considered complete rehabilitation of the mining areas, including dismantling of industrial and administrative infrastructure and closure criteria aiming to provide physical, chemical, biological and socio-economic long-term stability. The railroad and the port were considered to be reverted to the government in operating conditions in both cases.

For both cases, studies and actions that were identified from the risk assessment, gap analysis, opportunities analysis and any other sources were added to a master action plan (MAP). The MAP was prioritised ( $<1$ year, 1-3 years and $>3$ years) and assigned responsible persons, timelines and resources over the next three years leading to the next update of the closure plan. Actions beyond three years were captured to be included in future closure plan updates as required. From tracking and functionality perspectives, a comprehensive analysis was conducted to identify the feasibility of merging the MAP for each case into one single MAP; the analysis concluded that the merge was not only feasible. This outcome demonstrates that following the ICPS methodology, regardless of the case, will lead to similar actions, as the ultimate goal of any closure planning process is to deliver improved conditions after the cessation of the mining operations by analysing the onsite and local conditions. 


\section{Conclusion}

- Implementing the ICPS at Cerrejón has generated significant improvements both through realisation (e.g. identified opportunities) and prevention of destruction (e.g. identified closure risks) of value, especially for the Patilla pit that will be closed in the next five years.

- Involving a range of internal functions in the ICPS is critical to success.

- Taking a project-based approach to implementing the ICPS has provided the necessary rigour to facilitate execution of the plan.

- Following a risk-based approach (MCT and ICPS approach) is critical. Hence, the risk assessment is a cornerstone of good closure planning as it helps identify those risks that require additional mitigation either through further studies or identification of alternative closure criteria through benchmarking.

- Identifying success criteria as early as possible is critical so that an appropriate and aligned monitoring program can be developed, and areas can be concurrently assessed with maintenance undertaken if areas are deficient.

- Identifying KPIs for senior leaders and including them in operational performance contracts assist in obtaining the necessary ownership of closure-related components across a broad range of disciplines involved in the process.

- Following a structured approach to closure planning (MCT \& ICPS), and the subsequent implementation of the project plan, has been instrumental in clarifying the reversion and closure cases at Cerrejón mine.

\section{Acknowledgement}

The authors acknowledge Harley Lacy, Stantec, and Mike Slight, Mike Slight and Associates, who assisted in the original development of the ICPS. Also, a special acknowledgement to all Cerrejón employees who actively participated in the required workshops and the subsequent reviews. Additionally, the authors acknowledge Santiago Alcazar and Judith Flores from Golder Associates who were responsible respectively for the technical coordination and assessment of social aspects in the closure plan prepared in 2019.

\section{References}

Botha, PR 2013, Anglo American Mine Closure Toolbox (version 2), Anglo Operations Pty Ltd, London.

Cerrejón 2018, Sustainability Report 2017, Cerrejón, Bogotá.

Council of Standards Australia and Council of Standards New Zealand 2009, Risk Management - Principles and Guidelines (AS/NZS ISO31000), Council of Standards Australia and Council of Standards New Zealand, Australia.

Grant, CD 2006, 'Decommissioning Alcoa's first bauxite mine in the Jarrah Forest of Western Australia: cradle to grave', in AB Fourie \& M Tibbett (eds), Proceedings of the First International Seminar on Mine Closure, Australian Centre for Geomechanics, Perth, pp. 287-297.

Grant, CD \& Botha, PR 2015, 'Integrated closure planning: case studies on changing operational strategies to reduce closure liabilities', in AB Fourie, M Tibbett, L Sawatsky \& D van Zyl (eds), Proceedings of the 10th International Conference on Mine Closure, Australian Centre for Geomechanics, Perth, pp. 92-105.

Grant, CD \& Lacy, HWB 2016, 'Developing Anglo American's integrated closure planning system requires people, process and technology working together', in AB Fourie \& M Tibbett (eds), Proceedings of the 11th International Conference on Mine Closure, InfoMine Inc., Vancouver, pp. 581-594.

Grant, CD, Lacy, HWB \& Lambrechts, J 2016, 'Generating value through integrated closure planning at Cerrejon iron ore mine in South Africa', J Wiertz \& D Priscu (eds), Proceedings of the First International Congress on Planning for Closure of Mining Operations, Gecamin, Santiago.

Grant, CD, Slight, M \& Lacy, HWB 2018, 'Integrated closure planning systems: a structured approach to opportunities analysis creates significant value', in J Wiertz \& D Priscu (eds), Proceedings of the Second International Congress on Planning for Closure of Mining Operations, Gecamin, Santiago.

International Council on Mining and Metals 2019, Integrated Mine Closure: Good Practice Guide, 2nd edn, viewed 22 July 2019 , https://guidance.miningwithprinciples.com/integrated-mine-closure-good-practice-guide/ 